\title{
Elucidation of a "Signal-ON" Mechanism of Aggregation-Induced Emission Dye-Labelled DNA/DNA Duplexes and Application of a Repeat DNA Detection Method
}

Takashi Murashima*, Koji Kawamura and Ai Matsumoto

Department of Nanobiochemistry, FIRST (Frontiers of Innovative Research in Science and Technology), Konan University, Hyogo, Japan

\begin{abstract}
We reveal a fluorescence enhancement mechanism of an aggregation-induced emission (AIE)-DNA probe for target DNA detection. The enhancement is caused by the restriction of intramolecular rotation (RIR) effect that arises from steric hindrance between the AIE dye moiety in a hybridized probe and the dangling end (free-ssDNA) or peripheral dsDNA. Thus, these AIE-DNA probes can selectively detect two or more DNA repeat sequences, such as telomeric repeats.
\end{abstract}

Keywords: Aggregation induced emission; Telomeric repeats; Restriction of intramolecular rotation

\section{Introduction}

Aggregation-induced emission (AIE) dyes have attracted significant attention in the fields of bio-imaging [1,2] and bio-sensing [3-5]. These dyes exhibit drastically enhanced fluorescence due to aggregation and concomitant RIR [6,7]. The AIE phenomenon triggered by RIR is also observed when AIE dyes bind to target molecules [8,9]. Thus, when AIE dyes recognize and bind to target molecules the fluorescent intensity is enhanced. Therefore, AIE dye-based sensing is intrinsically a "SignalOn" mode, and is suitable for sensitive detection of biomolecules. AIE dye-modified biomolecular probes can be prepared easily to be selective for a target molecule owing to the high recognition ability of biomolecules, such as DNAs, peptide nucleic acids (PNAs), peptides, and proteins. Furthermore, the AIE dye has a signal switchover function. Thus, the AIE-labeled probe does not require the dual modification of the probe, such as a DNA molecular beacon, which has two different fluorophores at both ends of the DNA: the 5'- and 3 '-termini $[10,11]$.

The first report describing an AIE-dye-labeled DNA probe was revealed by $\mathrm{Li}$ et al. [12]. More recently, we have reported an AIEdye labeled PNA probe [13]. The behaviors of these two probes were completely different in aqueous media. In the case of the AIE-DNA, non-hybridized probes were dispersed and did not emit. However, once these probes hybridized with a DNA target, the fluorescent intensity was enhanced. In contrast, in the case of the AIE-PNA, nonhybridized probes aggregated to form nanoparticles because of the high hydrophobicity of PNA compared with DNA. These nanoparticles were found to emit brightly, but once hybridized, fluorescence quenching was observed. The explanation to this phenomenon was that the fluorescence quenching observed in duplex formation was attributed to the collapse of the PNA probe nanoparticles, which exhibited strong emission. From a sensing viewpoint, the signal-ON mode system is desirable and the fluorescence of an AIE-PNA/DNA duplex should also increase as well as an AIE-DNA/DNA duplex, according to the above-mentioned intrinsic property of AIE dyes. Thus, we have studied the mechanism of "Fluorescence-ON" in AIE-labeled DNA/DNA and AIE-labeled PNA/DNA duplexes, and the possible applications of AIElabeled probes.

\section{Materials and Methods}

\section{Materials and instruments}

All reagents for the synthesis of AIE dye were purchased from Wako Pure Chemical Industries, Ltd. (Osaka, Japan) and Tokyo
Chemical Industry Co., Ltd. (Tokyo, Japan), and used without further purification. DNA phosphoramidite monomer and coupling agents were purchased from Glen Research (VA, USA). Telomeric DNA and negative control DNA and other sequences were custom-synthesized by Hokkaido System Science Co., Ltd. (Hokkaido, Japan). DNA strands conjugated to AIE-probe was synthesized with 3400 DNA synthesizer (Applied Biosystem, USA). Synthesized AIE dye and AIE-probe were identified by ECA-500 NMR spectrometer (JEOL, Japan), ZQ 2000 LCMS (Waters, USA) or MALDI-TOF-MS (Bruker Daltonics, USA). Concentrations of DNAs and AIE-probes were determined using V630 spectrophotometer (JASCO, Japan). Fluorescence spectra were measured at $4^{\circ} \mathrm{C}$ using RF-5300PC spectrofluorometer (Shimazu, Japan) or FP-6200 spectrofluorometer (JASCO, Japan).

\section{Syntheses of TPA-COOH}

p-(Diphenylamino)benzaldehyde $(277 \mathrm{mg}, 1.01 \mathrm{mmol})$ and malonic acid $(530 \mathrm{mg}, 5.10 \mathrm{mmol})$ were dissolved in pyridine $(5 \mathrm{~mL})$, and piperidine $(0.25 \mathrm{~mL})$ was added to the solution. The mixture was heated at $80^{\circ} \mathrm{C}$ for overnight. After the reaction solution was cooled to room temperature, $1 \mathrm{M}-\mathrm{HCl}$ aq. was added to the mixture. The resulting precipitate was collected by suction filtration and washed with distilled water. The obtained light yellow powder was recrystallized from $\mathrm{MeOH}$ and the resulting orange crystal was dried under vacuo. Yield: $78 \%$ (248 mg, $0.787 \mathrm{mmol}) .{ }^{1} \mathrm{H}-\mathrm{NMR}\left(\mathrm{CDCl}_{3}, 500 \mathrm{MHz}\right): \delta(\mathrm{ppm}) 7.72$ $(\mathrm{d}, J=16 \mathrm{~Hz}, 1 \mathrm{H}), 7.39(\mathrm{~d}, J=8.5 \mathrm{~Hz}, 2 \mathrm{H}), 7.30(\mathrm{t}, J=8.0 \mathrm{~Hz}, 4 \mathrm{H}), 7.13(\mathrm{~d}$, $J=7.0 \mathrm{~Hz}, 4 \mathrm{H}), 7.12(\mathrm{t}, J=7.3 \mathrm{~Hz}, 2 \mathrm{H}), 7.01$ (d, $J=8.5 \mathrm{~Hz}), 6.29$ (d, $J=16$ $\mathrm{Hz}, 1 \mathrm{H}) .{ }^{13} \mathrm{C}-\mathrm{NMR}\left(\mathrm{CDCl}_{3}, 500 \mathrm{MHz}\right): \delta(\mathrm{ppm}) 172.57,150.27,146.78$, $146.65,129.58,129.51,126.89,125.51,124.15,121.41,114.11$. ESI-MS: $\mathrm{m} / \mathrm{z}$ calcd for $\mathrm{C}_{21} \mathrm{H}_{17} \mathrm{NO}_{2} ; 315.13$, found $316.20\left(\mathrm{M}+\mathrm{H}^{+}\right)$.

\section{Synthesis of Fmoc-Acp-Phosphoramidite}

Fmoc-Acp-ol (102 mg, $0.300 \mathrm{mmol})$ was suspended in DCM/

*Corresponding author: Takashi Murashima, Department of Nanobiochemistry FIRST (Frontiers of Innovative Research in Science and Technology), Konan University, Hyogo 650-0047, Japan, Tel: +81783031472; E-mail: murasima@konan-u.ac.jp

Received December 02, 2016; Accepted December 12, 2016; Published December 16, 2016

Citation: Murashima T, Kawamura K, Matsumoto A (2016) Elucidation of a "SignalON" Mechanism of Aggregation-Induced Emission Dye-Labelled DNA/DNA Duplexes and Application of a Repeat DNA Detection Method. Med Chem (Los Angeles) 6: 704-709. doi:10.4172/2161-0444.1000418

Copyright: (c) 2016 Murashima T, et al. This is an open-access article distributed under the terms of the Creative Commons Attribution License, which permits unrestricted use, distribution, and reproduction in any medium, provided the original author and source are credited. 
Citation: Murashima T, Kawamura K, Matsumoto A (2016) Elucidation of a "Signal-ON" Mechanism of Aggregation-Induced Emission Dye-Labelled DNA/DNA Duplexes and Application of a Repeat DNA Detection Method. Med Chem (Los Angeles) 6: 704-709. doi:10.4172/21610444.1000418

ACN $(4 \mathrm{~mL} / 1 \mathrm{~mL})$, and then DIPEA $(137 \mu \mathrm{L}, 0.800 \mathrm{mmol})$ was added dropwise to the solution. After the mixture was stirred for 5 min at room temperature, 2-cyanoethyl- $N, N$-diisopropylchlorophosphorami dite $(134 \mu \mathrm{L}, 0.600 \mathrm{mmol})$ was dropped and stirred for $10 \mathrm{~min}$. The solvent was evaporated off, and the residue was purified by column chromatography (DCM/ethyl acetate/TEA=5/1/0.01). The resulting phosphoramidite was immediately used for DNA solid phase synthesis.

\section{Syntheses of TPA-DNA probe using solid-phase peptide synthesis}

2-Cyanoethyl groups of oligonucleotides prepared were deprotected by flusing with $2 \%$ diisopropylamine in ACN $(3 \mathrm{~mL} \times 2)$ without cleavage from the solid support. Subsequently, Fmoc group was deprotected by using $20 \%$ piperidine in DMF ( $2 \mathrm{~mL}$ ) for $15 \mathrm{~min}$. The prepared resin was washed with $A C N$, and dried by blowing $\mathrm{N}_{2}$ gas.

TPA-COOH (15 mg) was dissolved in NMP containing $0.15 \mathrm{M}$ HATU, $0.15 \mathrm{M}$ HOBt and 0.3 M DIPEA. This solution was passed and filled on column with terumo syringes containing the prepared resin at either end of column. Coupling reaction was performed for $1 \mathrm{hr}$ $(\times 2)$. After the coupling reaction was finished, the resin was washed with ACN and dried by blowing $\mathrm{N}_{2}$ gas. Synthesized AIE-dye-labeled oligonucleotide was cleaved from the resin with $25 \% \mathrm{NH}_{4} \mathrm{OH}$, and deprotected for overnight at $55^{\circ} \mathrm{C}$. Crude TPA-DNA was purified by Sep-Pak C18 cartridge column (Waters) and HPLC using 0.01 M TEAA in MilliQ water and $0.01 \mathrm{M}$ TEAA in $\mathrm{MeOH}$. Total reaction scheme were shown in Figure 1. The TICT (Twisted-Intramolecular Charge Transfer) property of obtained TPA-DNA probe was confirmed by the observation of fluorescence quenching in polar solvents. Consequently, TPA-DNA probe emitted weak fluorescence in aqueous media.

\section{Results and Discussion}

In this paper, we report the behavior of AIE-labeled telomeric DNA (CCCTAA) ${ }_{1 \text { or } 2}$ probes in the presence of various types of DNA, including fully-matched DNA with the same length to probe sequence, telomeric repeat DNA of various lengths, mismatched DNA, and fullymatched/mismatched fused sequences. To investigate the relationships between fluorescence enhancement and probes/target interactions, the target sequence chosen was telomeric DNA [5'-(TTA GGG) - -3'] [14]. Telomeric DNA is a repeat sequence found at the end of chromosomes, [15] and the telomere is elongated by telomerase in tumor cells $[16,17]$. Therefore, telomere sequences are suitable for considering the assembly effect of an AIE dye and in the understanding of the "Fluorescence-ON" mechanism in AIE-labeled probe/DNA duplexes. Moreover, by using this target, we could investigate the applicability of the AIE-basedassay for cancer diagnosis as an alternative to the gel electrophoresis based TRAP assay [18]. The AIE dye chosen was a triphenylamine (TPA) derivative, and it was linked to the complementary strands of a 12-mer human telomeric repeat DNA (5'-CCC TAA CCC TAA-3').

The target sequences chosen for our study were 12, 24, 36, 48, 60, 72, and 84-mer human telomeric sequences [HT12, HT24, HT36,

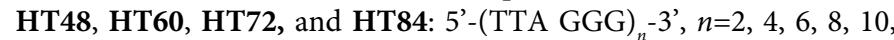
12, 14], negative control sequences [NC48: $5^{\prime}$-(TGA GTG) ${ }_{n}-3^{\prime}, n=2$, 8], complementary strand of the negative control sequences [NCC12, NCC48: 5'-(CAC TCA ) -3 ', $n=2,8]$, and a fully-matched/mismatched fused control sequence (HT-NC36: 5'-TGA GTG TGA GTG TTA GGG TTA GGG TGA GTG TGA GTG-3'). The corresponding TPA-labeled probe sequences used were TPA-DNA6 (5'-TPA-linker-(CCC TAA) $n^{-3}$ ') and TPA-DNA12 (5'-TPA-linker-(CCC TAA $\left.)_{2}-3^{\prime}\right)$. Details of the AIE dye and AIE probe syntheses are presented in the supplementary information (ESI).

The preparation of DNA samples for measuring was carried out as follows: i) HT, NC, NCC, and HT-NC DNA were diluted with ultrapure water and prepared to the required concentrations; ii) $5 \times$ Tris$\mathrm{HCl}$ buffer $(250 \mathrm{mM} \mathrm{LiCl}$ and $100 \mathrm{mM}$ Tris- $\mathrm{HCl}, \mathrm{pH}$ 7.5) was added $(40 \mu \mathrm{L})$; iii) the probe solution was added to each sample solution (total volume was $200 \mu \mathrm{L}$ ). Then, the mixtures were heated to $90^{\circ} \mathrm{C}$ for $2 \mathrm{~min}$ and then cooled to $4^{\circ} \mathrm{C}$ for $2 \mathrm{~h}$ in a thermal cycler.

First of all, we have investigated the fluorescent enhancement of an AIE probe in the presence of different lengths of telomeric DNA. Figure 2 shows the fluorescence spectra and increase ratio in the presence of each length of telomeric DNA (HT12-HT84). Each telomeric DNA sample concentration is as follows: HT12: $1 \mu \mathrm{M}$, HT24: $0.5 \mu \mathrm{M}$, HT36: 0.33 $\mu \mathrm{M}$, HT48: $0.25 \mu \mathrm{M}$, HT60: $0.20 \mu \mathrm{M}$, HT72: 0.167 $\mu \mathrm{M}$, and HT84: $0.143 \mu \mathrm{M}$. When each concentration was converted to the telomeric

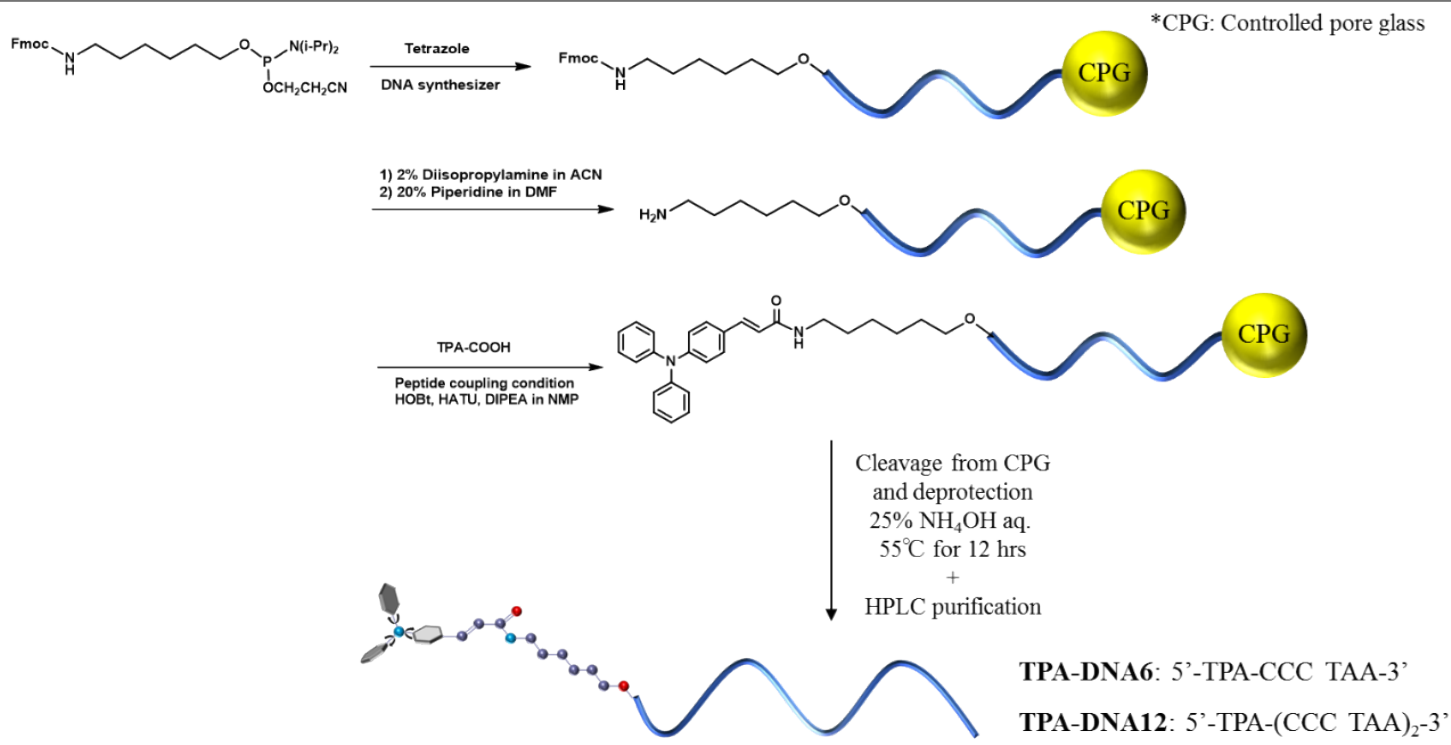

Figure 1: Reaction scheme of TPA-DNA probes. Oligonucleotides (6- and 12-mer) were synthesized on solid support (CPG) with DNA synthesizer. 
Citation: Murashima T, Kawamura K, Matsumoto A (2016) Elucidation of a "Signal-ON" Mechanism of Aggregation-Induced Emission Dye-Labelled DNA/DNA Duplexes and Application of a Repeat DNA Detection Method. Med Chem (Los Angeles) 6: 704-709. doi:10.4172/21610444.1000418

unit (12-mer: 5'-TTA GGG TTA GGG-3') concentration, all samples had the same concentration [e.g., HT48: 4 (Unit number) $\times 0.25 \mu \mathrm{M}$ (Concentration) $=1 \mu \mathrm{M}$ (Unit concentration); HT72: 6 (Unit number) $\times 0.167 \mu \mathrm{M}$ (Concentration) $=1 \mu \mathrm{M}$ (Unit concentration) $]. \mathrm{FI}_{\mathrm{s}}$ and $\mathrm{FI}_{0}$ represent the fluorescence intensity at $505 \mathrm{~nm}$ of the sample with telomeric DNAs (HT12-HT84) and without telomeric DNA (AIE probe only), respectively.

According to our previous studies, [19] the fluorescent intensities were proportional to the concentrations of repeated DNA unit (12mer: 5'-TTA GGG TTA GGG-3'). Thus, our prediction in advance was that all samples would exhibit approximately the same increase of fluorescence. In the case of HT24-HT84, the fluorescence were certainly comparable enhancement, while no fluorescence enhancement was observed with HT12. This is because when TPA-DNA12 (12-mer) and HT12 (12-mer) formed a duplex structure, the intramolecular rotation of the AIE dye moiety in the hybridized probe was not restricted owing to no steric hindrance (Figure 3). While in the case of HT24-HT84, the AIE moieties of the hybridized probes, except for termini, were influenced by the adjacent duplex and intramolecular rotations were restricted and fluorescence enhancement was observed.

When TPA-DNA6 (6-mer) was used as a probe towards HT12, an enhancement in the fluorescence was observed because two probe molecules can bind to HT12 (ESI). The essential point for fluorescence enhancement was the existence of peripheral dsDNA beside the AIE dye moiety, and consequent interference of intramolecular rotations. Fluorescence enhancement was found to not be concentration dependent for each TPA-DNA12/HT48 duplex concentration examined (ESI). Hence, intermolecular hydrophobic interactions among hybridized probes has not occurred, even multiple hydrophobic AIE probes bound to single telomeric DNA strands.

To investigate the effects of free-ssDNA and/or dsDNA at both ends of the target (telomeric) DNA, we have mixed a strand of telomeric DNA with the negative control sequence, which has a 12-mer telomeric unit and two 12-mer negative control sequence regions at both ends of the telomeric sequence (HT-NC36). The chosen negative control sequence showed no fluorescence enhancement when using NC48 and TPA-DNA12 as probes (ESI). Figure 4 shows the fluorescence increase ratio $\left(\mathrm{FI}_{\mathrm{s}} / \mathrm{FI}_{0}\right.$ ) of HT12/TPA-DNA12, HT-NC36/TPA-DNA12 (where ssDNA was present at the 3' and 5' dangling ends) and HT-NC36/TPADNA12+2eq. NCC12 (where dsDNA existed at both ends). When the dangling end or negative control dsDNA existed at the 3' end of the target strand, the fluorescence intensities were found to increase, and this was dependent on the HT-NC36 concentration.

Without regard to the concentrations, $\mathrm{FI}_{\mathrm{S}} / \mathrm{FI}_{0}$ of HT12 samples were approximately 1 . This means no fluorescence enhancement was observed owing to the lack of RIR effect, as mentioned above. In both ssDNA and dsDNA, the $\mathrm{FI}_{\mathrm{s}} / \mathrm{FI}_{0}$ values between $8 \mu \mathrm{M}$ and $4 \mu \mathrm{M}$ were almost identical. These results indicate the intrermolecular interaction did not affect the rotation of TPA moieties.

While, the clear difference of $\mathrm{FI}_{\mathrm{S}} / \mathrm{FI}_{0}$ was observed between ssDNA and dsDNA. As already reported, $[20,21]$ dsDNA is much more rigid than ssDNA, and the short length dsDNA. Thus, the reason for these differences in $\mathrm{FI}_{s} / \mathrm{FI}_{0}$ may be attributed to the difference in steric hindrance between flexible ssDNA and relatively rigid dsDNA.

We have reported previously the detection of telomeric DNA using an AIE-PNA probe [13]. In this report, we have shown that the fluorescent intensity diminishes as a function of the target DNA concentration. However, the fluorescence was not completely quenched, even in the saturated region. This indicates that the intramolecular rotation of AIE dyes is still restricted by steric hindrance of neighboring DNA/PNA hybrid duplexes in a similar manner to the present case.

Judging from these results, the AIE probe cannot detect the same length-fully-matched target DNA without a dangling end or peripheral dsDNA that interferes with the intramolecular rotation; therefore, two or more repeated DNAs are selectively detected. Otherwise, if the AIE probe can replace the corresponding strand, including a genomic duplex, the duplex may be detectable. Therefore, this system
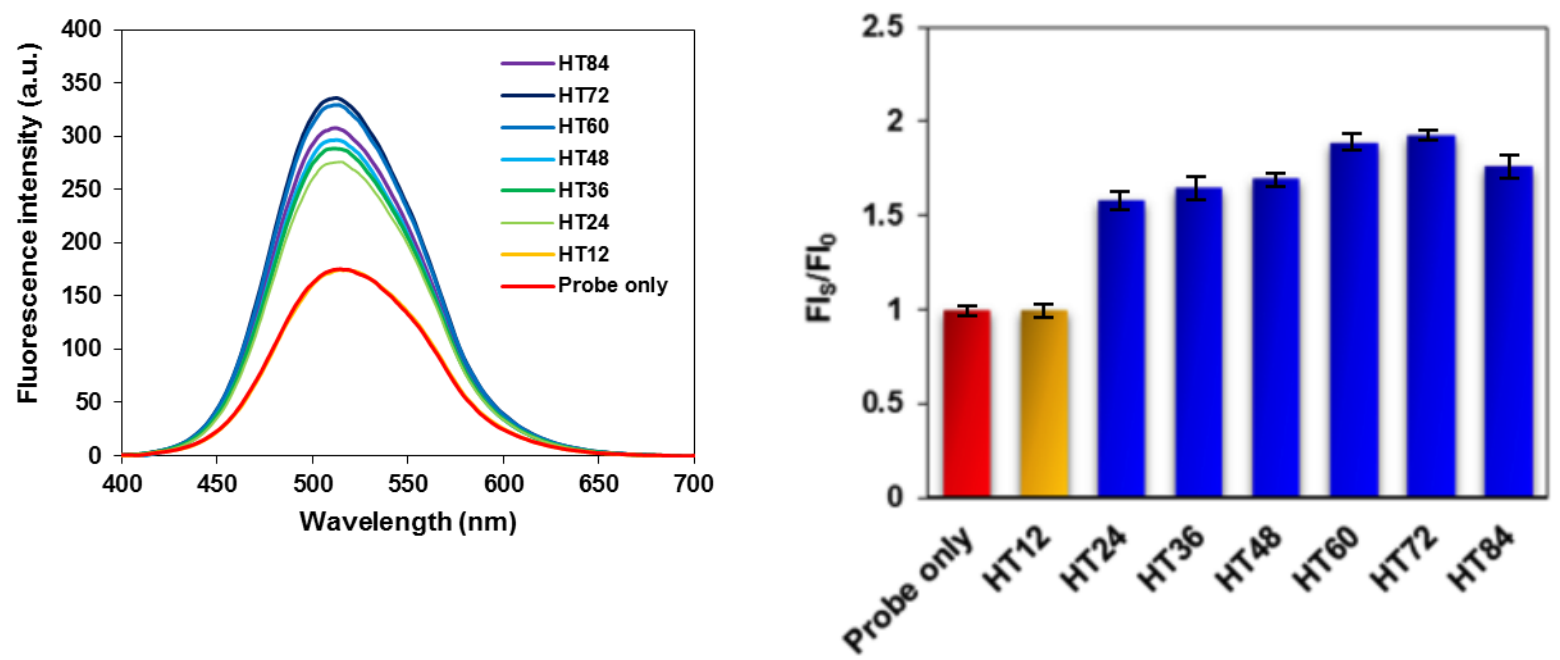

Figure 2: Fluorescence spectra of TPA-DNA12 in the presence of various telomeric DNAs (HT12-HT84) (left) and the increase in the fluorescence ratios (right; Error bars represent SD from $n=3$ ). [TPA-DNA12] $=3 \mu \mathrm{M}$, [HT12] $=1 \mu \mathrm{M}$, [HT24] $=0.5 \mu \mathrm{M},[\mathrm{HT} 36]=0.33 \mu \mathrm{M},[\mathrm{HT48}]=0.25 \mu \mathrm{M},[\mathrm{HT60}]=0.20 \mu \mathrm{M},[\mathrm{HT72}]=0.167 \mu \mathrm{M}$, [HT84] $=0.143 \mu \mathrm{M}$ in $50 \mathrm{mM} \mathrm{LiCl}$ and $20 \mathrm{mM}$ Tris- $\mathrm{HCl}$ buffer $\left(\mathrm{pH} \mathrm{7.5)}, 4^{\circ} \mathrm{C}, \lambda_{\mathrm{ex}}=360 \mathrm{~nm}\right.$. 
Citation: Murashima T, Kawamura K, Matsumoto A (2016) Elucidation of a "Signal-ON" Mechanism of Aggregation-Induced Emission Dye-Labelled DNA/DNA Duplexes and Application of a Repeat DNA Detection Method. Med Chem (Los Angeles) 6: 704-709. doi:10.4172/21610444.1000418

\section{a) TPA-DNA12 and HT12}

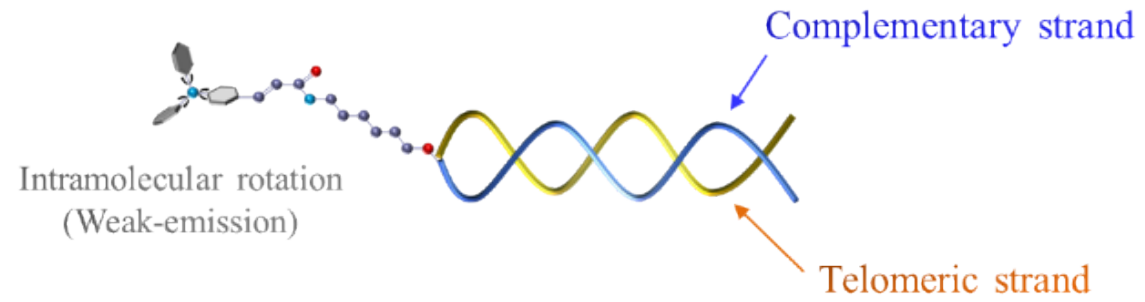

b) TPA-DNA12 and HT24-HT84

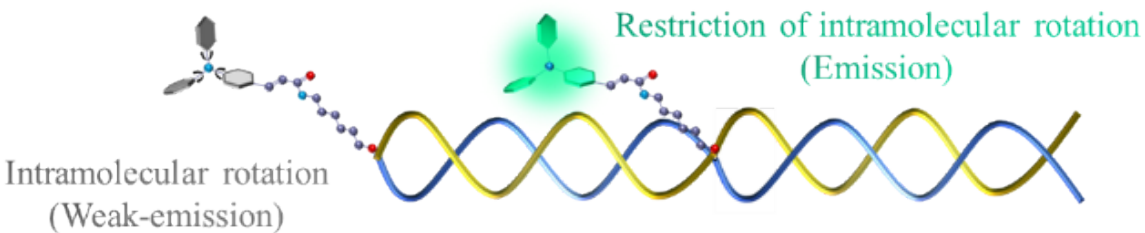

Figure 3: Schematic of the fluorescence enhancement mechanism by restriction of intramolecular rotations. (a) TPA-DNA12 and HT12, (b) TPA-DNA12 and HT24-HT84.
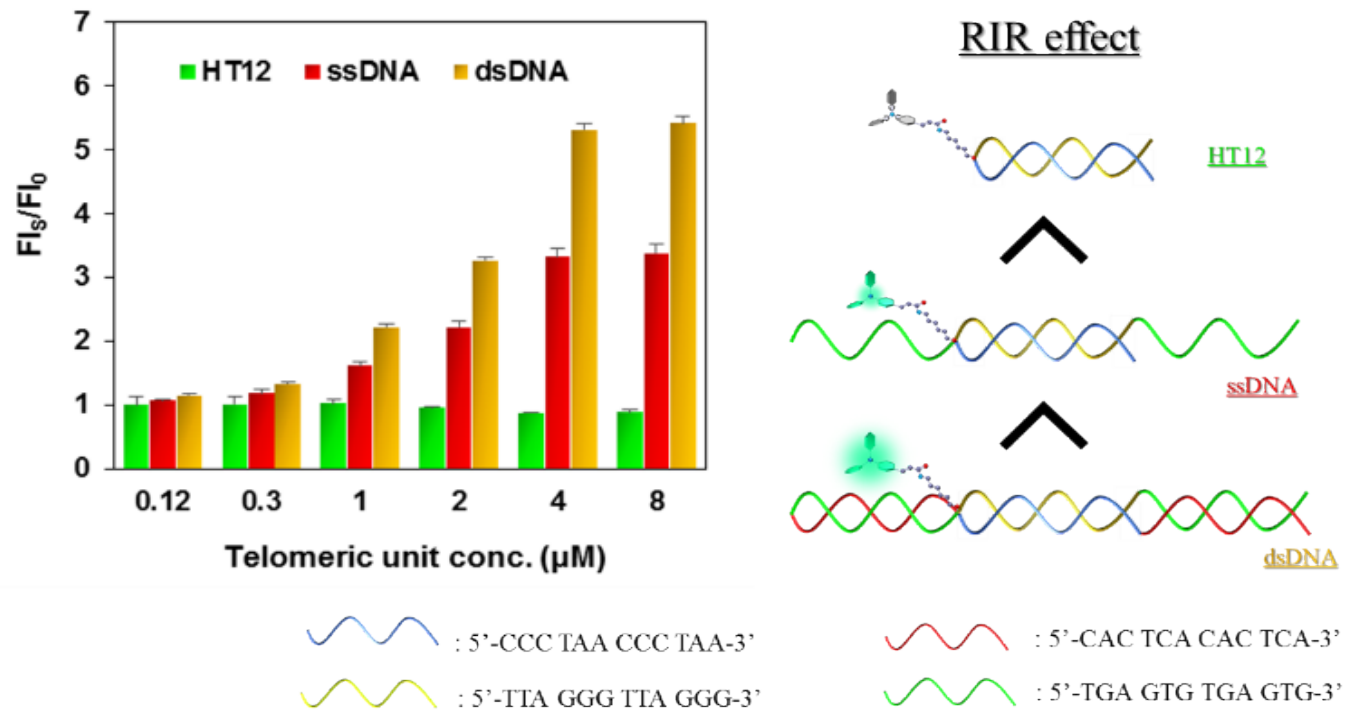

Figure 4: Fluorescence increase ratio of $3 \mu \mathrm{M}$ of TPA-DNA12 and 0.12-8 $\mu \mathrm{M}$ of HT12, HT-NC36, and HT-NC36/NCC12 in $50 \mathrm{mM}$ LiCl and $20 \mathrm{mM}$ Tris-HCl buffer (pH 7.5), r.t., $\lambda_{\text {ex }}=360 \mathrm{~nm}$ (left). Strength of the RIR effect of the AIE dye in HT12, HT-NC36 (ssDNA), and HT-NC36/NCC12 (dsDNA) (right). Error bars indicate the standard error of the mean for $n=3$.

may be applied to determine single-nucleotide polymorphisms [22]. When these probes are applied to biological samples, it is necessary to consider the effect of chromosomal DNA. In other words, a DNA detection probe requires high selectivity towards the target DNA, even in the presence of other DNAs. For example, in our previous report describing a telomeric DNA detection method with an induced FRET system, ethidium bromide [23] and the intercalator were found to interact with chromosomal DNA, thereby influencing the signal response [19]. Thus, we investigated the efficiency of the AIE probe for quantification of telomeric DNA under the coexistence of decoy dsDNA. Figure 5 shows the $\mathrm{FI}_{\mathrm{s}} / \mathrm{FI}_{0}$ without (blue) or with (red) 10 $\mu \mathrm{M}$ dsDNA (NC48/NCC48). The result shows that the AIE probe can quantify telomeric DNA using either condition. In other words, the AIE dye moiety did not intercalate between DNA base pairs, and the restriction of intramolecular rotation of the AIE probe was not influenced by the coexistence of dsDNA.

\section{Conclusions}

We have revealed a fluorescence enhancement mechanism of an AIE probe during target detection. The enhancement is caused by the RIR effect, which arises from steric hindrance of a dangling end (free-ssDNA) or peripheral dsDNA. In the case of an AIE probe/fully- 
Citation: Murashima T, Kawamura K, Matsumoto A (2016) Elucidation of a "Signal-ON" Mechanism of Aggregation-Induced Emission Dye-Labelled DNA/DNA Duplexes and Application of a Repeat DNA Detection Method. Med Chem (Los Angeles) 6: 704-709. doi:10.4172/21610444.1000418

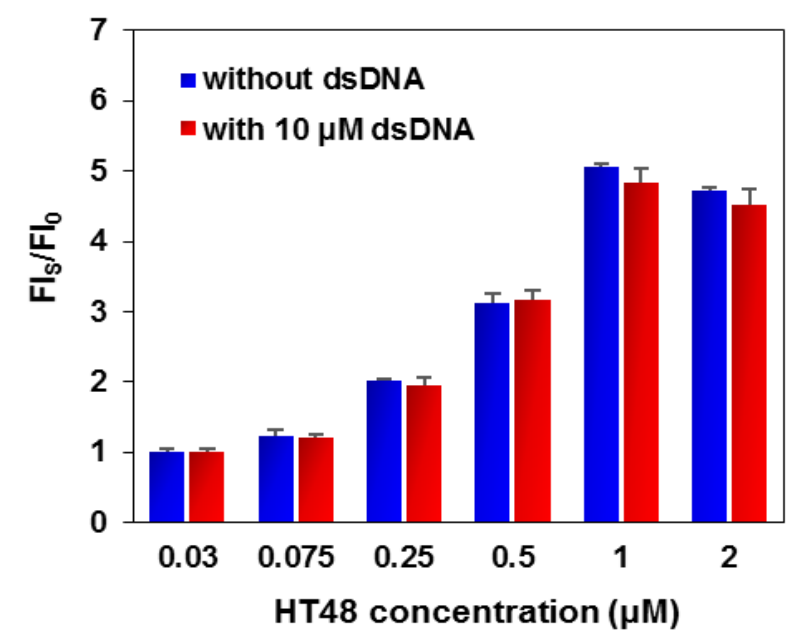

Figure 5: Fluorescence increase ratio of $3 \mu \mathrm{M}$ TPA-DNA12 and 0.03-2.0 $\mu \mathrm{M}$ HT48 without (blue) or with $10 \mu \mathrm{M}$ dsDNA (red) in $50 \mathrm{mM} \mathrm{LiCl}$ and $20 \mathrm{mM}$ Tris$\mathrm{HCl}$ buffer $\left(\mathrm{pH}\right.$ 7.5), r.t., $\lambda_{\mathrm{ex}}=360 \mathrm{~nm}$. dsDNA: NC48/NCC48. Error bars indicate the standard error of the mean for $n=3$.

matched DNA duplex, the degrees of free intramolecular rotation and the surrounding environment were approximately equal to the AIE probe. Therefore, at least two or more repeat DNA units are required for selective detection with the AIE probe, and non-repeat DNA was also detected when a dangling end or peripheral dsDNA existed in the probe-target duplex, e.g., TPA-DNA12/HT-NC36 and TPA-DNA12/ HT-NC36/NCC12.

Because the AIE-labeled probe does not require dual modification with two different fluorophores or a fluorophore and quencher such as a DNA molecular beacon, probe preparation is rather convenient. Furthermore, the AIE-labeled probe is not influenced by other dsDNA molecules, which is unlike the induced FRET method with an intercalator. Many AIE dyes with various emission wavelengths have been reported [24-28]; therefore, we can choose the most suitable dye for a particular purpose. In addition, this detection concept can be applied to a DNA assay using an AIE PNA probe that has higher thermal stability (higher $T_{\mathrm{m}}$ values) and improved recognition ability. From these viewpoints, this facile and simple DNA detection technique will open a new way for the detection of single nucleotide polymorphisms and repetitive DNA sequences, such as telomeres and triplet repeats $[29,30]$ with low-cost, facile probe design, and synthesis.

\section{Acknowledgements}

This work was supported in part by a Grant-in-Aid for Scientific Research (C) (No. 16K08952) from the Japan Society for the Promotion of Science.

\section{References}

1. Yu Y, Feng C, Hong Y, Liu J, Chen S, et al. (2011) Cytophilic Fluorescent Bioprobes for Long-Term Cell Tracking. Adv Mater 23: 3298-3302.

2. Zhang X, Wang K, Liu M, Zhang X, Tao L, et al. (2015) Polymeric AlE-based nanoprobes for biomedical applications: recent advances and perspectives. Nanoscale 7: 11486-11508.

3. Noguchi T, Shiraki T, Dawn A, Tsuchiya Y, Lien LTN, et al. (2012) Nonlinear fluorescence response driven by ATP-induced self-assembly of guanidiniumtethered tetraphenylethene. Chem Commun 48: 8090-8092.

4. Shao A, Guo Z, Zhu S, Zhu S, Shi P, et al. (2014) Insight into aggregationinduced emission characteristics of red-emissive quinoline-malononitrile by cell tracking and real-time trypsin detection. Chem Sci 5: 1383-1389.
5. Hong $Y$, Xiong H, Lam JWY, Häußler M, Liu J, et al. (2010) Fluorescent Bioprobes: Structural Matching in the Docking Processes of AggregationInduced Emission Fluorogens on DNA Surfaces. Chem Eur J 16: 1232-1245.

6. Hong Y, Lam JWY, Tang BZ (2009) Aggregation-induced emission: phenomenon, mechanism and applications. Chem Commun 4332-4353.

7. Luo J, Xie Z, Lam LWY, Cheng L, Chen H, et al. (2001) Aggregation-induced emission of 1-methyl-1,2,3,4,5-pentaphenylsilole. Chem Commun 1740-1741.

8. Hong Y, Lam JWY, Tang BZ (2011) Aggregation-induced emission. Chem Soc Rev 40: 5361-5388.

9. Liu Y, Deng C, Tang L, Qin A, Hu R, et al. (2010) Specific detection of D-glucose by a tetraphenylethene-based fluorescent sensor. Journal of the American Chemical Society 133: 660-663.

10. Horejsh D, Martini F, Poccia F, Ippolito G, Caro AD, et al. (2005) A molecular beacon, bead-based assay for the detection of nucleic acids by flow cytometry. Nucleic Acids Res 33: e13.

11. Goel G, Kumar A, Puniya AK, Chen W, Singh K (2005) Molecular beacon: a multitask probe. J Appl Microbiol 99: 435-442.

12. Li Y, Kwok RTK, Tang BZ, Liu B (2013) Specific nucleic acid detection based on fluorescent light-up probe from fluorogens with aggregation-induced emission characteristics. RSC Adv 3: 10135-10138.

13. Kawamura K, Matsumoto A, Murashima T (2015) Facile DNA Detection Based on Fluorescence Switching of A Hydrophobic AIE Dye-Labeled Peptide Nucleic Acid Probe by Aggregation/ Disaggregation. Int J Med Nano Res 2: 011.

14. Moyzis RK, Buckingham JM, Crams LS, Dani M, Deaven LL, et al. (1988) A highly conserved repetitive DNA sequence, (TTAGGG)n, present at the telomeres of human chromosomes. Proc Natl Acad Sci USA 85: 6622-6626.

15. Blackburn EH (1991) Structure and function of telomeres. Nature 350: 569-573

16. Kim NW, Piatyszek MA, Prowse KR, Harley CB, West MD, et al. (1994) Specific association of human telomerase activity with immortal cells and cancer. Science 266: 2011-2015.

17. Shay JW, Bacchetti S (1997) A survey of telomerase activity in human cancer. Eur J Cancer 33: 787-791.

18. Kim NW, Wu F (1997) Advances in quantification and characterization of telomerase activity by the telomeric repeat amplification protocol (TRAP). Nucleic Acids Res 25: 2595-2597.

19. Kawamura K, Yaku H, Miyoshi D, Murashima T (2014) A simple "add and measure" FRET-based telomeric tandem repeat sequence detection and telomerase assay method. Org Biomol Chem 12: 936-941.

20. Liedl T, Sobey TL, Simme FC (2007) DNA-based nanodevices. Nanotoday 2 36-41.

21. Qu J, Wu L, Liu H, Li J, Lv H, et al. (2015) A Novel Electrochemical Biosensor Based on DNA for Rapid and Selective Detection of Cadmium. Int J Electrochem Sci 10: 4020-4028

22. Venter JC, Adams MD (2001) The sequence of the human genome. Science 291: 1304-1351.

23. Olmsted J, Kearns DR (1977) Mechanism of ethidium bromide fluorescence enhancement on binding to nucleic acids. Biochemistry 16: 3647-3654.

24. Kamino S, Horio Y, Komeda S, Minoura K, Ichikawa H, et al. (2010) A new class of rhodamine luminophores: design, syntheses and aggregation-induced emission enhancement. Chem Commun 46: 9013-9015.

25. Kubota Y, Kasatani K, Takai H, Funabiki K, Matsui M (2015) Strategy to enhance solid-state fluorescence and aggregation-induced emission enhancement effect in pyrimidine boron complexes. Dalton Trans 44: 3326-3341.

26. Hu R, Lager E, Aguilar AA, Liu J, Lam JWY, et al. (2009) Twisted Intramolecular Charge Transfer and Aggregation-Induced Emission of BODIPY Derivatives. J Phys Chem C 113: 15845-15853.

27. Kokado K, Chujo Y (2011) Multicolor Tuning of Aggregation-Induced Emission through Substituent Variation of Diphenyl-o-carborane. J Org Chem 76: 316-319. 
Citation: Murashima T, Kawamura K, Matsumoto A (2016) Elucidation of a "Signal-ON" Mechanism of Aggregation-Induced Emission Dye-Labelled DNA/DNA Duplexes and Application of a Repeat DNA Detection Method. Med Chem (Los Angeles) 6: 704-709. doi:10.4172/21610444.1000418

28. Chakrabarti MC, Schwarz FP (1999) Thermal stability of PNA/DNA and DNA DNA duplexes by differential scanning calorimetry. Nucleic Acids Res 27: 4801-4806.
29. Zoghbi HY, Orr HT (2000) Glutamine repeats and neurodegeneration. Annu Rev Neurosci 23: 217-247.

30. Ashley CT, Warren ST (1995) Trinucleotide repeat expansion and human disease. Annu Rev Genetics 29: 703-728. 